\title{
Social Capital Transformation, Voluntarily Services and Mental Health during Times of Military Conflict in Ukraine
}

\author{
Kateryna Karhina ${ }^{1}$, Mehdi Ghazinour ${ }^{2}$, Nawi $\mathrm{Ng}^{1,3}$ \& Malin Eriksson ${ }^{4}$ \\ ${ }^{1}$ Department of Public Health and Clinical Medicine, Epidemiology and Global Health, Umeå University, Umeå, \\ Sweden \\ ${ }^{2}$ Police Education Unit at Umeå University, Umeå, Sweden \\ ${ }^{3}$ Center for Demographic and Aging Research, Umeå University, Umeå, Sweden \\ ${ }^{4}$ Department of Social Work, Umeå University, Umeå, Sweden \\ Correspondence: Kateryna Karhina, Department of Public Health and Clinical Medicine, Epidemiology and \\ Global Health, Umeå University, Umeå, Sweden. E-mail: kateryna.karhina@gmail.com
}

Received: January 16, 2017 Accepted: February 14, 2017 Online Published: March 13, 2017

doi:10.5539/gjhs.v9n5p141 URL: https://doi.org/10.5539/gjhs.v9n5p141

\begin{abstract}
Background: The effects of war as well as military conflict include long-term physical and psychological harm to children and adults. Social relations and trust play a role in peace building and conflict resolution. Social capital is believed to facilitate institutional and interpersonal trust as well as safety and security, and thus may become an important resource in times of military conflict.
\end{abstract}

Objective: The aims of this study are to analyse how social capital may be transformed due to a military conflict in contemporary Ukraine and to explore the role of voluntarily services in this change. Further we aim to discuss the possible influence of social capital transformation on mental health in times of military conflict.

Methods: A qualitative case study design was chosen to explore it. In-depth interviews were chosen as a method for data collection. Informant's selection criteria were: either to be involved in volunteering activities in the city of Khmelnitsky (which is the place of research) or to receive volunteering help. 18 interviews were conducted.

Informants were reached by snowball sampling. Interviews are collected, transcribed, translated and analyzed using constructive Grounded Theory approach of Charmaz.

Results: Our results show that social capital transforms during military conflict experiences. The changes happen both in cognitive and structural components since they are connected. The most important changes occur in bonding social capital, where new formation such as brotherhood, emerges and replaces previous bonding ties with family and friends. In addition, voluntarily acting actors (those who normally belong to bridging social capital) transform into relations with bonding entities. New forms of social capital are thus generated through the existence of voluntarily services, and these networks provide essential social support in times of military conflict. Perceived support softens negative emotional responses to traumatic events. In line with the stress-buffering model, our results support that the formation of new social capital in times of military conflict may protect against the negative mental health effects of these experiences.

Keywords: social capital, crisis, influence on health, volunteering, military conflict

\section{Introduction}

War has a tragic effect on health and on mental health of the population in particular. The effects of war include long-term physical and psychological harm to children and adults, as well as reduction in material and human capital. Research confirms that war causes more mortality and disability than any major disease (Murthy \& Lakshminarayana, 2006). The WHO estimated that, in situations of armed conflicts throughout the world, $10 \%$ of people experiencing traumatic events will have serious problems with mental health and another $10 \%$ will develop behaviour that hinders their ability to function effectively (WHO, 2001). War or military conflict is not just a private experience but also a collective social suffering having secondary consequences on religious, political, economic and social relations (including family) as well (Kienzler, 2008; Summerfield, 2000). 


\subsection{The Recent Military Conflict in Ukraine}

The case of Ukraine in Eastern Europe illustrates just another military conflict experience in the world. Due to the recent conflict situation in Ukraine since 2014, more than 275,000 people have been displaced in Ukraine. Some 172,000 people have applied for asylum in neighbouring countries in Europe, and another 149,000 people have applied for other forms of legal stay in the Russian Federation (UNHCR, 2015). The Ukrainian movement called Revolution of Dignity, or later Euromaidan, started in November 2013 and was followed by tremendous changes in lives of Ukrainians. One of the consequences was the Crimea annexation. Later, in April 2014 when the Russian president mentioned the concept of Novorossiya (literally translates as "New Russia", which derives from the old Russian history when a part of modern Ukraine was incorporated into the Russian Empire) the fear of replication of the Crimean scenario became a realistic threat (Giuliano, 2015).

The new reform-oriented government was supported at elections by the majority of voters, but opponents still initiated protests that were supported by the Russian Federation. As a result, a highly politicized armed conflict occurred between the Ukrainian government and the separatists' units, supported by neighbouring countries. There is no agreed-upon definition of how the armed conflict that still takes place in the Eastern part of Ukraine is termed. In Ukraine it is called $A T O$ which means anti-terrorist operation, while people who face it call it war and mass media calls it a hybrid war. There is no scientific census how to define the conflict in Ukraine - either an internationalized non-international armed conflict or non-international armed conflict (Heinsch, 2015). But all of these definitions include military conflict.

Since the Ukrainian eastern oblasts, Luhansk and Donetsk, "proclaimed" independence thousands of people have been killed and around a million more have been displaced. This armed conflict brought political, economic and social instability as well. During the conflict several rounds of mobilization took place all over Ukraine where men that had completed military training before were drafted to take part in military actions. Some of the soldiers went to protect their land voluntarily without having even basic clothing and anti-bullet protection. As a result of material scarcity and fear of the enemy coming further into the country, volunteering and the setting up of voluntary services centres emerged to respond to the needs of the protectors/soldiers. In the majority of cases these were either formalized or informal activities in the very beginning, but later there were unities/services created and officially documented as civic organizations. This is a unique case since Ukraine is considered to be a country with a very low level of civic engagement (Gatskova \& Gatskov, 2016). In addition, according to the Global Peace Building Index (based on 23 qualitative and quantitative indicators) Ukraine ranks 156 out of 163 countries, indicating that Ukraine scores very low in peace building and that violence is growing (Global Peace Index, 2016).

\subsection{The Role of Social Support in Times of Military Conflicts}

Recent attention was brought towards the role of social relations and trust in peace building and conflict resolution (Cox, 2008). Social capital is believed to foster peace, facilitate institutional and interpersonal trust and support, as well as safety and security, and may thus become an important resource in times of military conflict. But at the same time it can become a negative tool to facilitate development of the military conflict (Cox, 2008; Deng, 2010; Heinecken, 2015).

Scholars agree that social support - often viewed as an outcome of social capital - can be a powerful protective factor from negative mental health effects of war experiences. High prevalence of mental health problems such as anxiety, depression and PTSD (posttraumatic stress disorder) after experiencing war have been found in studies e.g. from Afghanistan (Cardozo et al., 2004; Miller, Omidian, Rasmussen, Yaqubi, \& Daudzai, 2008; Scholte et al., 2004). A study from Cyprus explored non-formal survival strategies during the war and found that family social support was a strong protective factor (Mehmet \& Mehmet, 2004). Another study from Turkey stressed that social and family support together with preparedness for torture may be protective against PTSD after experiencing torture and war trauma (Johnson \& Thompson, 2008). An empirical study from Yugoslavia found that the role of civic organizations of women played a significant role in peace-building strategies (Korac, 2008). Further, a study from Sudan about strengthening bonding ties in a violent community illustrates the importance of social capital formations in times of war (Deng, 2010). The effects of armed conflict on trust were also explored in study from Uganda (De Luca \& Verpoorten, 2015). They (ibid) found a rapid recovery of previously decreased trust after the violent conflict. A positive association between mental ill health and lack of physical and emotional support during and after a period of war have also been found in studies conducted in Chechnya, Iraq, and in Israel (Murthy \& Lakshminarayana, 2006).

Lack of social support is quite often reported together with poor health among war-affected people from all over the world (Brewin, Andrews, \& Valentine, 2000). Major models of social support and health include psychological stress as an important pathway with higher levels of social support being related to lower perceptions of stress and 
less mental health problems (Uchino, Bowen, Carlisle, \& Birmingham, 2012).

The level of social capital differs among societies and may also fluctuate over time due to societal changes (Carlson, 2016). In Ukraine social capital is considered as low compared to many other countries, characterized by low levels of institutional, generalized trust and low civic engagement (Karhina, Ng, Ghazinour, \& Eriksson, 2016). Tremendous changes in society like two massive civic protests in less than 10 years, military conflict in the territory in addition to transition prehistory from Soviet past can't leave a society without any changes. Given the comparatively low levels of social capital in Ukraine, the recent experience of civically organized and well-spread voluntarily services during the ongoing military conflict, constitute a quite unique and interesting event. Despite the fact that social capital has been utilized in numerous studies within many research fields, there is a lack of knowledge on how social capital develops and changes in periods of societal crises and how this in turn may influence mental health of population (Carlson, 2016; Eriksson \& Emmelin, 2016; Heinecken, 2015). This study aims to fill this gap.

\subsection{Aim of the Study}

The aims of this study are to analyse how social capital may be transformed due to a military conflict in contemporary Ukraine and to explore the role of voluntarily services in this change. Further, we aim to discuss the possible influence of social capital transformation on mental health in times of military conflict.

\subsection{Theoretical Framework}

The concept of social capital has become commonly utilized within public health research during the last decades. It includes three main elements: social networks, norms of reciprocity, and trust (Eriksson, 2011; Ferlander, 2007). Further, these elements are conceptualized as two different types of social capital. Structural social capital includes "roles, rules, precedents and procedures as well as a wide variety of networks that contribute to cooperation" (Uphoff, 2000 p.218). Hierarchical relations that are unequal and involve power are seen as vertical; while more or less equal relationships are viewed as horizontal (Whiteford, Cullen, \& Baingana, 2005). Cognitive social capital includes "mental processes and resulting ideas, reinforced by culture and ideology, specifically norms, values, attitudes, and beliefs that contribute to cooperative behaviour" (Uphoff, 2000 p.218). Norms of reciprocity and trust thus fit into the cognitive aspect of social capital.

In addition, trust can be divided into different forms, i.e. social trust (generalized trust), which is confidence in other people; and institutional trust - trust in the formal system. Both types of trust can have generalized or specific forms (Ferlander, 2007). Eriksson (2011) subdivides trust into "thick" which is informal networks with strong ties between people who are similar to each other. The other one - informal "thin" trust involves people that are different to other people (Eriksson, 2011). Trust is important and may have influence on life satisfaction, happiness, well-being and optimism, health, community, civil society, participation and democracy (Delhey \& Newton, 2003).

Social networks constitute the main element of social capital, and can also be divided into different forms. By level of formality social networks can be formal and informal. Formal networks may explain the contacts within voluntary organizations and between citizens and civil servants. Ferlander (2007) mentions that these kinds of networks may provide access to formal support, i.e. informational support and support from different agencies. Informal networks include contacts with friends, neighbours, family, and colleagues, and might be an important source of emotional support. In addition, social networks might be characterized by the strengths of ties within the social network: strong ties are often occurring in intimate relations with family and close friends and weak ties are often developed in non-intimate social networks that are not frequently maintained (Ferlander, 2007). By levels of diversity social networks are characterized as bonding - containing ties between people that are similar in terms of demographic factors and thus homogeneous, and bridging - which includes people with a variety of social identities and is thus heterogeneous. Further, linking social capital contains vertical connections of people in a power hierarchy and may include formal and informal links (Ferlander, 2007).

Social networks may substantially influence both physical and mental health through social support. Epidemiological studies show that lower levels of support lead to higher mortality rates, especially from cardio-vascular disease, lower cancer and infectious disease mortality (Uchino et al., 2012). Social support can thus be viewed as an outcome of social capital in that involvement in social networks characterized by reciprocity norms, may increase access to social support (Berkman \& Glass, 2000). Further, social support can be divided into:

- emotional support - provides trust, care, acceptance, encouragement, concern, love or empathy. In other words, it gives the feeling of value to the individual;

- instrumental support (tangible support) - provides material goods, financial help or services. It gives 
practical help that assists individuals;

- informational support - provides suggestions, advice, guidance, useful information. It gives the potential for problem-solving;

- companionship support - provides the sense of belonging by spending social time with others (Berkman \& Glass, 2000; Ferlander, 2007).

\section{Methods and Material}

\subsection{Study Design and Setting}

This qualitative grounded theory study was conducted in the city of Khmelnitsky in Western Ukraine, which is an administrative centre for the whole oblast in this part of the country (in total, Ukraine is divided into 24 oblasts). The population of Khmelnitsky is more than 267,000 people and the city has a geographical location that connects railways and highways of Central Europe to the Black Sea. The economy of the oblast in general mostly deals with transport, agriculture and energy industry. The oblast is half rural and half urban. This city was one of the leading places for drafting men to the army in the recent military conflict (KHMdepo, 2016). This means that a lot of men are at ATO (Anti-terrorist operation) or were there, and their families are thus directly or indirectly involved in the conflict as well.

A qualitative case study design was chosen to explore how social capital changes during times of military conflicts. Grounded theory based on Charmaz's constructivist approach was used for data collection and analysis (Charmaz, 2014). Voluntary service centres in Ukraine were selected as the "case" since they illustrated an "empirically real and bounded, but specific" case that could be explored in order to answer our research questions (Ragin, 1992). Our case is bounded in time, activity and place (Baxter \& Jack, 2008). Further, this selected case could be utilized to bring "theory (i.e. social capital transformation) and practice (i.e. military conflict) together in a special way" (Wieviorka, 1992). Thus, the case-study qualitative approach was used to explore the phenomena that took place at a certain point in time by using multiple perspectives, i. e. the views of volunteers, combatants and their family members (Wieviorka, 1992). For the purpose of this paper we will call the situation in the East of Ukraine as military conflict, the place where it happens - military conflict zone (while informants quite often call it war and war zone).

\subsection{Sampling of Informants}

Informant's selection criteria were either who were involved in volunteering activities or had received volunteering help, i. e. be a utilizer of volunteering services. Social capital providers i.e. volunteers are hereafter called volunteers in this paper, while informants quite often refer to those who have joined military forces of Ukraine voluntarily. They also call them volunteers, but we will mention that those volunteers represent military forces volunteers. By utilizers we refer to people that received social capital benefits from those who are called volunteers in this paper.

Informants were reached by snowball sampling. Initially, two informants that were known to the researcher as volunteers were invited. They were contacted by phone and invited to take part in the study. After the invitation and a brief oral and written information about the study, informants had a choice to either decline or participate. Approached volunteers were very eager to share their experiences. The only difficulty was to find the time for the interview since they were very busy with their activities and daily life. All invited volunteers agreed to participate in the study.

Utilizers were more difficult to be reached and approached since they were either soldiers at the military conflict zone, soldiers who were demobilized from the military conflict zone or relatives of soldiers at the military conflict zone. All those who got the invitation to participate in the study agreed in advance, but two injured soldiers at the hospital declined their participation later. Their reason for declining was that they were not ready to share their military conflict experiences yet (because it was emotionally tough for them). Table 1 presents the sociodemographic characteristics of the informants. 
Table 1. Sociodemographic characteristics of the informants

\begin{tabular}{|c|c|c|c|c|c|}
\hline \multicolumn{3}{|l|}{ Volunteers (Providers) } & \multicolumn{3}{|l|}{ Utilizers } \\
\hline Sex, age & Occupation & $\begin{array}{l}\text { Length of the } \\
\text { interview }\end{array}$ & Sex, age & Occupation & $\begin{array}{l}\text { Length of the } \\
\text { interview }\end{array}$ \\
\hline Woman, 23 & $\begin{array}{l}\text { Head of a charity } \\
\text { foundation }\end{array}$ & 80 minutes & Man,35 & $\begin{array}{l}\text { Soldier, previously an } \\
\text { electrician. }\end{array}$ & 40 minutes \\
\hline $\begin{array}{l}\text { Woman, } \\
\text { grandmother, about } \\
50\end{array}$ & $\begin{array}{l}\text { Interpreter, } \\
\text { teacher }\end{array}$ & 56 minutes & Man, 25 & $\begin{array}{l}\text { Soldier (officer), } \\
\text { previously an agricultural } \\
\text { engineer }\end{array}$ & 45 minutes \\
\hline Woman, 36 & Lawyer & 55 minutes & Man, 35 & $\begin{array}{l}\text { Soldier handicapped by } \\
\text { war }\end{array}$ & 67 minutes \\
\hline Woman, about 35 & Psychologist & 55 minutes & Man, 30 & Professional officer & 80 minutes \\
\hline $\begin{array}{l}\text { Woman } \\
\text { (grandmother), about } \\
55\end{array}$ & Local authority & 70 minutes & Woman, 54 & $\begin{array}{l}\text { Medical worker, mother } \\
\text { of a soldier }\end{array}$ & 50 minutes \\
\hline $\begin{array}{l}\text { Woman } \\
\text { (grandmother), about } \\
50\end{array}$ & $\begin{array}{l}\text { Local deputy } \\
\text { member }\end{array}$ & 60 minutes & $\begin{array}{l}\text { Woman, } \\
\text { about } 30\end{array}$ & $\begin{array}{l}\text { Furniture designer, wife of } \\
\text { a soldier }\end{array}$ & 50 minutes \\
\hline Woman, about 50 & Entrepreneur & 80 minutes & Man, 28 & Worker, driver & 90 minutes \\
\hline Man, about 40 & Railway worker & 35 minutes & $\begin{array}{l}\text { Woman, } \\
\text { about } 60\end{array}$ & $\begin{array}{l}\text { Pensioner, mother of a } \\
\text { soldier }\end{array}$ & 40 minutes \\
\hline Woman, 38 & Entrepreneur & 45 minutes & & & \\
\hline Woman, about 45 & Psychologist & 75 minutes & & & \\
\hline
\end{tabular}

\subsection{Data Collection}

Individual in-depth interviews were performed during two research visits to this city in May-July 2015. All the interviews had different lengths and dynamics, but lasted between 30 and 90 minutes and were conducted at the place preferred by each informant. Two languages were used for the interviewing, Ukrainian and Russian, since the first author is a native speaker of both, informants could choose the language they preferred. Interviews were performed in a positive climate since people wanted to share their experiences despite the fact that some of the interviews were very emotional. Since there are two different groups of informants, two different sets of questions were used for the interview.

Besides questions about personal experience of volunteering (either provision or utilization) questions concerning institutional, interpersonal and generalized trust were discussed as well as health issues and experiences about their previous and present available social networks. In addition, questions of social experiences in the army were discussed with soldiers. With providers of volunteering the topics of their experiences were conversed.

\subsection{Analysis}

As stated above, Grounded theory based on Charmaz's constructivist approach was used for data collection and analysis (Charmaz, 2014). The analytical process started with approaching the data inductively with an open mind. Data consisted of interviews and memos that were taken immediately after interviews. Further, the analytical process involved iterative strategies of going back and forth between data and the preliminary concepts generated.

The interviews were transcribed, translated and coded facilitated by using Open Codes software (Open Codes 3.4). Initial coding that included line-by-line coding was used as the first step. Coding allowed us to look at the interviews in a different way and helped to create preliminary ideas that were used at the next stage of clustering. The codes were clustered using the sensitizing concept "social capital" as the basic idea at the centre. Later the data was sub-clustered into several smaller parts while codes that did not fit into these emerging analytical clusters were taken out of the further analysis. Among each small sub-cluster, the connections of ideas and codes were identified. Sketches and drawings were done manually to understand relations between codes. Until this stage, the process was characterised by initial coding that helped us to get started and get acquainted with the data. Next, all developed clusters with their assigned codes were further explored and compared against each other, i.e. utilizing 
the principle of constant comparisons (Charmaz, 2014), which helped to generate the categories.

After this, theoretical coding was carried out. In this stage, we used our tentative ideas that were generated at previous stages and these ideas were now checked for properties of the categories. This helped to construct robust categories, but also helped to clarify the relationship between the categories. In addition, this process helped to see the transformation of social capital after experiencing military conflict. This final step of the analysis was characterised by an abductive reasoning technique when theoretical explanations for the data were checked by returning back to the data for its re-examination. During the whole analysis process, our analytical memos were of great help to find connections between the categories and coming up with a model to illustrate these.

Figure 1. Examples of quotations, open codes and categories

\begin{tabular}{|c|c|c|}
\hline Quotation & Open code & Category \\
\hline $\begin{array}{l}\text { "Well, now we communicate with volunteers more. They } \\
\text { are more normal people. And those who were friends } \\
\text { before now moved to the background". }\end{array}$ & $\begin{array}{l}\text { Experiencing friends becoming more } \\
\text { distant }\end{array}$ & \multirow{2}{*}{$\begin{array}{l}\text { Becoming } \\
\text { separated from } \\
\text { the closest ones }\end{array}$} \\
\hline $\begin{array}{l}\text { "I asked him how it was there, were things quite ok? But } \\
\text { he replied: "I am not at a health resort". He protected us } \\
\text { and didn't tell anything". }\end{array}$ & Protecting family by keeping silence & \\
\hline $\begin{array}{l}\text { "She (means volunteer) calls to the military unit and they } \\
\text { say that guys are ok, not wounded. Sometimes we have no } \\
\text { connection for 5-6 weeks and she says "Don't worry. I did } \\
\text { call them. They are fine". }\end{array}$ & $\begin{array}{l}\text { Providing mother with information } \\
\text { about her son }\end{array}$ & \multirow{2}{*}{$\begin{array}{l}\text { Getting bridging } \\
\text { supporters }\end{array}$} \\
\hline $\begin{array}{l}\text { "Then I introduced her to my brother and she started } \\
\text { contacting my mother because she didn't know where I } \\
\text { had been for some time. She explained her everything". }\end{array}$ & Contacting the families of the soldiers & \\
\hline
\end{tabular}

\subsection{Ethical Considerations}

Ethical approval from the Regional Ethical Board in Umeå, Sweden was obtained (Dnr 2013/447-31Ö). All participants signed informed consent in advance of the interview and were notified about the overall aims of the study and how the information from the interview would be used and analysed.

The researcher (the first author) approached the informants in an informal and "friendly" manner, still following the ethical guidelines in research. It was easier to approach combatants (soldiers) in an informal way, since an official atmosphere risked scaring the participants and making them become more reserved. That was also why the informants got to choose the places for the interviews. In most cases, the informants chose to meet at the volunteer centres, but two interviews took place at different cafés (chosen by the informants), and few took places outdoors in parks that allowed a quiet and relaxed atmosphere (since it was summer time and the weather nice enough to stay outside as much as possible). Several interviews were conducted at 3 different hospitals. Very sensitive issues were not approached until the interviewer was sure that the respondent was comfortable enough to discuss them. As a trained psychologist the interviewer could help respondents to feel comfortable enough to talk about unpleasant memories and things. At the end of each interview, the interviewer asked about the feeling of each of the informants. The interviewer stayed with the informant until both felt comfortable enough after discussion. The majority of the respondents mentioned that they felt relieved after sharing things that no one asked them about in ordinary life.

\section{Results}

The analysis resulted in the generation of seven categories describing social capital transformation due to military conflict and the role of voluntarily services in these changes. In this section, we first present the generated categories that explain social capital transformation during military conflict, and thereafter we present a model illustrating how these categories are related to each other.

\subsection{Becoming Separated from the Closest Ones}

Many codes describe how informants become separated from their families and friends both emotionally and physically while being in a military conflict zone or while returning from there. The strongest ties that bonded them for years before become weaker because of two different realities that exist concurrently: a peaceful reality of 
their families with an active social life versus the armed military reality with constant danger and social isolation. Many codes reflected the misunderstandings that exist from the civilian life dwellers towards those who still can't switch into peaceful reality from the military actions. Our data shows that to deal with this situation soldiers simply live in their own world by separating from everyone who doesn't have similar experiences. Friends, who had the same interests and problems before military actions now experience how the values of those who took part in military actions have changed, while those who remain in their civilian life stay similar; a fact that creates misunderstandings between people. Further, data indicates that families, who were waiting for their men to return back as soon as possible didn't expect them to return different and changed: their life hasn't changed as rapidly as the life of their men who served in the army. As a result, these military experiences separate friends and families both emotionally and physically.

"There are some guys who become very reserved and say nothing and there is no way to know anything from them".

Volunteer

In our interpretation, this category describes changes in bonding social capital. Bonding social capital, i.e. the closest people like family, friends, changed a lot after experiencing military conflict. Those actors (mostly those who were involved in military action) experience a weakening of the strongest ties they had before. This happens mainly because they want to protect their families from the difficulties that they have faced in the war themselves:

"Firstly, we couldn't discuss such issues on the telephone. Such issues are not discussed. And in general, everything is fine. I asked him: "How is it there? Quiet?" He replies: "I am not at a health resort!". He protected us and did not tell anything. He lost much weight! He worked hard! But it is not a problem! We would feed him! It is not a problem!"

Wife of a killed soldier

\subsection{Developing Brotherhood}

This category was developed based on codes describing how new bonding formation develops during military conflict experiences. Our informants describe how people, who have never met before (or never had a similar dangerous experiences) live, eat, sleep and fight against a joint enemy and experience physical and emotional difficulties together. Strong trust is reflected in these codes. Our data shows how trust was created among those who have shared similar experiences of military conflict life and have experienced the need for any kind of support. Further, these fraternal feelings are brought back to civic life and stay as strong as they were in the military conflict zone. Experience of saving each other's lives, collecting money for the surgeries of injured combatants and simply sharing the same feeling of danger, hunger and standing against the enemy create a feeling of very strong bonds between each other according to our data. Shared memories and the possibility to talk openly and be understood increases the value and importance of having this resource available.

"My relationship changed because now I got friends who were not friends, but brothers with whom I went through trials and learned a lot!"

Injured soldier

In our interpretation, this illustrates how new bonding social capital is created in a military conflict that functions as a substitute for the previous units of bonding social capital (civic friends and family) that is partly lost due to the conflict situation. These new bonding links have fraternity feeling and in this study we call it brotherhood. The support that combatants get out of it was not possible in civilian life: they support each other emotionally, financially, physically. The most important aspect in this brotherhood is that each of them is ready to sacrifice his life in order to save the others.

"Well... but I am sure of my combatants as we well as they are of me! They will never abandon me! Never! When I had a surgery they collected money for my surgery from there! They were there and it was hard there!"

Injured handicapped soldier

\subsection{Getting Bridging Supporters}

The role of volunteers, who balance the situation between relatives and soldiers and transfer the information from one to the another is described in this category. Volunteers describe how they are those, who find the need in one side and bring it to the other; those who provide emotional, tangible, instrumental support to the soldiers and to their families. Through active involvement in instrumental support and responsibilities that they have decided to carry out, volunteers gain enough trust to support soldiers and ex-soldiers emotionally. Our informants describe 
how emotional issues connect volunteers to families of the soldiers and they thus become the bridge between the military and the peaceful reality of the city. Our data indicates how volunteers quite often fulfill the role of psychologists and mentors to those who have lost their peaceful reality. Volunteers help in adapting back to a civilian life for those who were involved in military actions or for those who suffered from them. They help the families of those who are away in the East. According to our informants, this help includes: medical help, material and financial help to kids and elderly parents, legal support and emotional resources to those who have a need of sharing. They try ways to help and support that others don't dare to use.

"My relatives say: "I do want to call you, but I am afraid of calling you extra! Perhaps for you not to cry". They are at distance, but want to help! And Volunteers! ...Volunteers call and try".

Wife of a killed soldier

Despite the quite challenging problems faced by the relatives of soldiers in the military zone, the volunteers provide help and support. Beyond providing instrumental support, our data also indicates that volunteers function as a "bridge" between two realities: peace and war.

\subsection{Feeling Abandoned by Government Creates Distrust}

Our informants describe in detail how the Ukrainian population has full distrust to the government and authorities of the country. A lot of codes reflect people's high distrust to the highest authorities. Even if there is agreement about the existence of distrust, the way it was presented differed: from just mentioning the fact - up to aggressive threats towards concrete personalities. Informants express how people put the blame from their losses (physical and material) on the shoulders of the leaders of the country. The leaders are seen as those who don't stop the conflict that takes lives as well as mental well-being out of those who live in fear of the military actions. Informants blame government for not fulfilling medical care to those who protect the borders of the country, not providing materially for those who risk their lives, subtracting so called "army tax" out of salaries and pensions and not accounting for the use of the money. Being without uniforms and special equipment in the zone where weapons shoot, being hungry or thirsty because of the lack of provision or seeking money for the surgeries that were caused by injuries from the military actions are considered as shameful and unfulfilling of the state responsibilities and full separation from the common people and their problems.

"Though yesterday our President spoke; we do not believe him. It is a dual game! Dual, or even threefold!"

Volunteer

In our interpretation, this category illustrates how linking social capital - mostly represented by institutional involvement, but also military and governmental institutions - transforms due to the conflict situation. Before experiencing the military conflict, the level of trust was low in the society, but after facing the military conflict, trust level decreases even more rapidly.

"But the most important is that our government is abandoning us! It does not pay any attention to medical treatment, to nothing! We had many of those who were killed... many... and we said that he was dead. But they sent papers to his home that he was missed in action! It is done for the reason of not paying the compensation! Or when they were under the debris for two-three months and then when they were buried the state has no other way out! And there such guys who were torn into pieces - but they (the state) gave the documents that they had been missed in action! We can't stand any more - this state's scoffing!"

Twice injured demobilized soldier

\subsection{New Bonding Relations Substitute for Mistrust in Others}

This category is constructed based on codes that describe the attitudes towards generalized trust and how it varies among different people: our codes talk about full mistrust in strangers and up to desire to trust newly met strangers. The results of our analysis indicate that new bonding relations characterized by high trust seem to substitute for low trust in others, in those who don't understand the experiences of military conflict life. Informants describe how volunteers, who were not even familiar to the soldiers and their families before the military conflict, become very close to them now. Misunderstandings among old friends and other people who don't want to accept that there is an armed conflict in their country, combined with lack of community involvement increases mistrust in others. On the contrary our informants also describe how those who are close and ready to share the hardships (both emotional and physical), despite being strangers before, substitute mistrust in others by creating trust. A lot of codes illustrate the trust that develops towards those who don't hide themselves from the danger, but come to the armed conflict zone just to support them, by bringing necessary equipment and provision, i.e. the volunteers.

"To somebody for better, to somebody for worse! I began trusting somebody more, and stopped trusting others!" 
"People did not see that war! They say: "There is no war, there is an armistice there!" They even say: "Who sent you there? Why did you go there?" It hurts me! If we did not go there, they would have been here! If we had not stopped them there, they would have been here where our family and, children are. People do not understand it! And it makes me sad!"

Ex-military servant

\subsection{Restructured View of Safety}

The understanding of safety that informants had before experiencing military conflict and how this has changed is explored in this category. It includes both physical and emotional experiences of safety. Codes illustrate how physical safety stops being important after coming through experiences of military conflict, while financial and political unsafety become more important. Further, our informants mention how emotional safety stops being as it was before. Flash-backs of traumatic experiences and memories are described as common among those who returned from the military conflict, influencing the well-being not only for the soldiers, but also their families. A lot of codes illustrate how soldiers feel most safe when they are at the military conflict zone together with their combatants whom they trust most of all, which may sound paradoxical because this is an extremely dangerous place to be. In addition, volunteers are described as risking their lives physically and facing emotional violence from those who don't share their active involvement in supporting the soldiers. The informants express how the volunteers' understanding of safety changes as well.

"When I just came from there (military conflict zone), I didn't feel safe at all! At all!"

Injured soldier

"As for our situation it is dangerous. The danger is psychological, social and physical".

Volunteer

From our data it is clear that the feeling of safety of both volunteers and those who are actively involved in military actions transform due to their experiences. Some of them don't feel physical danger and prefer the places where it is extremely dangerous, but some of them continue their activities despite the present danger. Partially this seems to be connected with changed networks of social participation.

"You know... this is an interesting question and I could reply "of course it is safe there (at the military conflict zone)". But I should mention that there is a support there... we support each other and do the same work there. It is better for me there; there is different life there! I do not say about those who come back inadequate..."

Military officer

\subsection{Wanting to Reciprocate to Soldiers}

This category developed based on codes with information about the desire of volunteers to reciprocate to those who take military duties and protect their country and their people. To reciprocate to these soldiers, the informants talk about how volunteers want to help them and their families as much as they could. This desire is proved by spending less time with their families sometimes. Our data describes how volunteers are ready to talk over the phones at night (just when those who are at the military conflict zone need to talk). They bring provision to a dangerous zone just because they know that it is needed, and they connect with their families and transfer the information both ways. Further, the informants describe how volunteers ask for the needs and try to find the resources and provide everything that is needed, they give legal support and help with documents when soldiers come back, they think about medical treatment, preventive mental measures, spread information in media, produce protective clothes, cook homemade food, and organize others to help soldiers and much more. In any situation they try to understand those who came through armed hardships and make their lives easier in this or that way.

"In the very beginning I canned food alone, then I involved my neighbors, then my friends canned food in their villages and in the city. We knew that it was the war and we canned for ourselves less and gave more for our warriors. It was so pleasant to help them! Somebody gave 100 jars, somebody 200, 300 and even 500! We have something to give to our warrior for the whole winter".

Volunteer

\subsection{Summary-the Transformation of Social Capital during Military Conflict}

Below we present a figure summarising how social capital transforms due to experiencing military conflict, and the role played by voluntarily services in this transformation (Figure 2). 


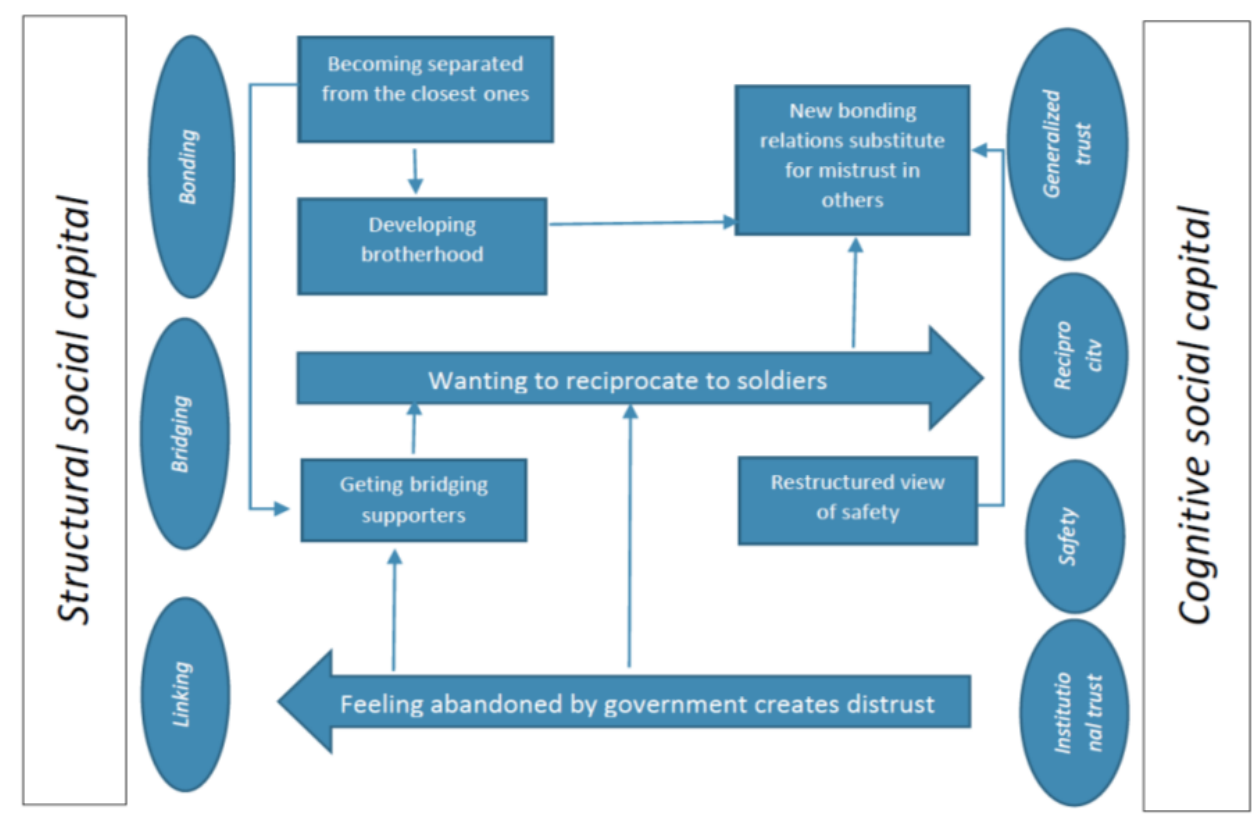

Figure 2. Social capital transformation due to military conflict experiences.

Figure 2 illustrates how social capital transforms by experiencing military conflict. Changes occurred both in bonding, bridging and linking social capital due to these experiences. The category "Becoming separated from the closest ones" is a form of bonding structural social capital. Becoming separated from the closest ones due to the experiences of being at the military conflict zone leads to stronger bonds with others, who came through similar experiences, illustrated by the category "Developing brotherhood". This happens because of the danger and everyday activities that were shared with those people whom they call brothers after living together. They have protected each other's lives, which made them very close to each other. Everything that is connected to the military reality is discussed with combatants; that is why this category belongs to bonding social capital. The categories that fit into bridging social capital are "Getting bridging supporters" and "Wanting to reciprocate to soldiers". It is clear from our data that volunteers become bridging supporters because they want to reciprocate to soldiers. Linking social capital is represented by the category "Feeling abandoned by government creates distrust". This category is dual and also is a part of cognitive social capital in institutional trust. The arrow here comes from institutional distrust and feelings of being abandoned into distrust that is "created" or formed. The category "Wanting to reciprocate to soldiers" also means that this desire is fulfilled and people do show that they want to reciprocate. That is why it also fits into structural and cognitive social capital at the same time. The part of "wanting" - belongs to reciprocity and the part of "doing so" fits into structural bridging social capital. The arrow here comes from structural to cognitive, because the desire comes before the action. "Restructured view of safety" belongs to cognitive social capital and represents the safety that has changed due to military conflict experiences and reflects transformed feelings. Generalized trust here is represented by the category "New bonding relations substitute for mistrust in others" and includes generalized mistrust in humanity, but the examples that were met by informants "force" them to change mistrust into trust with bonding relations.

The connections at this model are represented with the arrows. So, "Becoming separated from the closest ones" leads to "Developing brotherhood" and this impacts generalized trust by the category "New bonding relations substitute for mistrust in others". "Becoming separated from the closest ones" is also connected to the category "Getting bridging supporters" which is connected to "Wanting to reciprocate to soldiers" category. "Feeling abandoned by government creates distrust" also influences the category "Wanting to reciprocate to soldiers". "Restructured view of safety" is connected to "New bonding relations substitute for mistrust in others" in a way that new bonding relations provide the feelings of safety.

\section{Discussion}

In summary, our results show that all forms of social capital are being transformed in one way or another due to experiencing military conflict: some of them are destroyed and some new ones are emerging. 


\subsection{Transformation of Bonding Social Capital}

Our results indicate that the relations with families and friends often deteriorate due to the military conflict. The changes at the family level happen due to military conflict. Existing bonding social capital (family and friends) before the military conflict is restructured and a new form of "Brotherhood" becomes very important. This new bonding social capital seems to almost completely substitute for the family. In addition, friends from the military conflict zone seem to continue playing a very important role after returning to civilian life. These new forms of bonding ties are highly reciprocal and provide all forms of social support (emotional, instrumental, informational and companionship) to those taking part in these networks. In addition, volunteering support helps to re-connect with the family. So, some families of those who are involved in the military conflict develop relations with volunteers as well, but they seem not to be as strong as with those who are involved in the military. The development of stronger bonding ties with those who are supposed to belong to bridging networks is not a new phenomenon among those who have experienced war. In line with our results, other studies also reported that this may happen when existing bonding links disappear or become less significant (like former friends) and when there is a need to substitute them - bridging ties come to help (De Luca \& Verpoorten, 2015). In their study from Cyprus, Mehmet and Mehmet (2004) found how within - and between families informal social capital became the main source of survival in times of civil war (Mehmet \& Mehmet, 2004). In some other wars, family reunion becomes a very important issue as well, like as it is shown in studies from Chechnya, Israel, and Afghanistan (Murthy \& Lakshminarayana, 2006; Summerfield, 2000).

\subsection{Transformation of Bridging Social Capital}

Our results also show how bridging social capital changes as well during a military conflict. A lot of colleagues and neighbours do not share the patriotic views of those who went to protect the land from invasion or just want to be not involved in the conflict personally. As a result - it separates them. In addition, the connection with the military conflict zone part is not always good and relatives don't know what the real situation of their relatives is. In such a situation, volunteers play a significant role because they can connect the family with their family member at the conflict zone when this connection is destroyed. This is a new network of those people who were not involved in it before the military conflict emerged. This can be viewed as a new form of social capital emanating from new needs due to the military conflict. As such, it is hard to know for how long these bridging networks will continue to exist in the future. Misunderstandings and opposing views from community members toward the volunteers and their active civic engagement influence the relation of volunteers as well. As a consequence, negative bridging connections to other community members (neighbours) make (new) bonding relations with the military zone participants only stronger.

\subsection{Transformation of Linking Social Capital}

Linking social capital describes the trust in authorities and the links to politicians. Ukraine has a tradition of corruption among and distrust in the authorities (Gatskova \& Gatskov, 2016). This distrust is inherited from the one leading party to the other and doesn't make vertical relations strong in the society. Especially it can be seen in such a critical situation as a military conflict when people meet disabilities, lose friends, get mental injuries and have unstable political and economic situations.

Institutional trust is classified as thin trust and comes out of bridging and linking relations with authorities and politicians that people experience (Eriksson, 2011). The existence of strong institutional distrust is one of the findings of this study. Institutional trust influences linking social capital. Eriksson and Emmelin, following Portes and Woolcock, stress that emerging social networks are determined by the existing socio-political situation. They (ibid) argue that strong bonding social capital among certain community members (such as members of volunteering groups) may develop as a response to the lack of political support, economic instability and inequality (Eriksson \& Emmelin, 2016). Our study supports this reasoning as well. The strong bonds between soldiers and volunteers could be seen as a result of institutional distrust and feeling of being abandoned by their government and other politicians.

Transitional countries are usually found to be low in social capital and Ukraine is not an exception (Gatskova \& Gatskov, 2016; Portes, 1998). However, our results also indicate that the military conflict may become a catalyser for building and strengthening social capital. Stolle (2003) states that social capital includes a triad of relationships between state, civic society and family which in connection creates various sources of it (Stolle, 2003). He also states that the role of family usually stays abandoned but in reality it impacts attitudes (including trust) and involvement in civilian life (Stolle, 2003). Our findings support this: breaking family ties and disconnection from the authorities are "compensated" by active members of civic society, which reshapes previously existing forms of social capital. 
Civic engagement influences generalized trust of people i.e. volunteering emerges and by helping unfamiliar people it affects trust. Generalized trust, also considered as thin trust, comes out of bridging and linking relations that people experienced (Eriksson, 2011). This was also quite low before experiencing the military conflict but our results indicate that it changed during the military conflict. Being separated from civilian life at the military zone ruins bonds with previous friends and colleagues and worsens generalized trust. On the other hand, finding new networks and receiving help from unfamiliar volunteers helps to restore and build new generalized trust. Changes in generalized trust due to war and military conflict are also documented elsewhere. For example, the civilian war in Uganda (2000-2012) resulted in a decline in associational membership (which is an important component of social interactions) and led to decrease in generalized trust (De Luca \& Verpoorten, 2015). However, it may be a temporary response to a highly critical situation for those who experience (d) military conflict. It is quite possible that by the time social interactions are recovering or re-created, generalized trust will return since critical situations may change trust permanently or temporarily.

\subsection{How Might the Transformation of Social Capital and Voluntary Services Effect Mental Health?}

It is well known in existing literature that social support is a protective factor for health including mental health (Berkman \& Glass, 2000; Ferlander, 2007; Murthy \& Lakshminarayana, 2006; Summerfield, 2000; Uchino et al., 2012). A traumatic event due to war provokes fear, helplessness, or horror in response to the threat of injury or death. People, who are exposed to military conflicts' traumatic events are at increased risk for PTSD as well as for the major depression, panic disorder, generalized anxiety disorder, and substance abuse, as compared with those who have not experienced traumatic events (Kessler, Sonnega, Bromet, Hughes, \& Nelson, 1995).

A previous quantitative study by Brailey and colleagues found that unit cohesion had a strong impact on life experiences among people with PTSD (Brailey, Vasterling, Proctor, Constans, \& Friedman, 2007). These results go in line with the stress-buffering model of social ties and mental health, stating that perceived support prevents negative emotional responses. This model is adapted from Cohen and reproduced and explained by Kawachi and Berkman (Kawachi \& Berkman, 2001). The model explains how social support buffers against stress through two mechanisms: first, while having the expectation that the stressful event will happen - it prevents the possible negative response to it; second, the decrease of reaction to stress happens during experience of the outcome of the stress (Cohen \& Wills, 1985). We did not investigate how the (transformation of) social capital influenced mental health of our informants, but it is clear from our results that the new social capital that was generated due to the military conflict resulted in various forms of social support. The provision of instrumental support (e.g. provision with food, necessary equipment, funds, medical drugs etc.) dominates when stress was created by economic factors primarily. In addition, informational support was provided by volunteers (e.g. volunteers' help with documentation needed in order to get social benefits, link returned soldiers to specialized non-governmental organizations that help them to adjust etc.). When the loss of companionship (such as family) is a source of stress then it would be buffered by new companionship (with volunteers). In addition, our results support that social companionship and instrumental support are especially effective when they are connected to a specific need induced by a stressful event (Cohen \& Wills, 1985).

Our data shows that voluntarily services try to help soldiers and their families and sometimes substitute the necessary bonding ties by themselves. They provide instrumental, companionship, informational as well as emotional support for utilizers of their services. Volunteers provide mostly instrumental support by providing financial help and material goods. Volunteers provide informational support such as advice and problem solving suggestions. By providing instrumental and informational support, they also provide companionship support. They spend time together and provide a sense of belonging. Instrumental support aims to protect and cure health, while companionship and emotional support mostly help with mental health issues.

By providing these forms of supports, emotional support is created and it later creates trust and provides care, encouragement, concern and empathy. It helps the warriors to understand their value, which they lack from the government. Volunteers may thus provide primary help with PTSD in different ways: they help to inform the family members how to behave with those who have just returned from the military conflict zone; they also help them to connect with the others. Thus, in line with the stress-buffering model as well as other empirical studies, one could assume that the support provided by the new generated social capital during military conflict in our study context, in addition, has a positive effect of the mental health of those involved in these networks.

A recent study from Ukraine about mental disorders in individuals participating in armed conflict in the East of Ukraine mentions inability to adapt and re-integrate into peaceful society and former social life as one of the problems of post-war veterans (Sas \& Yastremska, 2016). When injured soldiers feel abandoned by government, volunteers search for those that need their help. When the need is satisfied, volunteers try to follow up with their 
"clients" and this creates strong ties.

\section{Conclusions}

Our results show that social capital transforms during military conflict experiences. The changes happen both in cognitive and structural components since they are connected. The most important changes occur in bonding social capital, where new formation such as brotherhood emerges and replaces previous bonding ties with family and friends. In addition, volunteers (those that normally belong to bridging social capital) develop relations with bonding entities. New forms of social capital are thus generated through the existence of voluntarily services, and these networks provide essential social support in times of military conflict. Perceived support softens negative emotional responses to traumatic events. In line with the stress-buffering model, our results support that the formation of new social capital in times of military conflict may protect against the negative mental health effects of these experiences.

\section{Competing Interests Statement}

The authors declare that there is no conflict of interests regarding the publication of this paper.

\section{References}

Baxter, P., \& Jack, S. (2008). Qualitative case study methodology: Study design and implementation for novice researchers. The Qualitative Report, 13(4), 544-559. Retrieved from http://nsuworks.nova.edu/tqr/vol13/iss $4 / 2$

Berkman, L. F., \& Glass, T. (2000). Social integration, social networks, social support, and health. In L.F. Berkman \& I. Kawachi (Eds.) Social epidemiology, 1, 137-173. New York: Oxford University Press.

Brailey, K., Vasterling, J. J., Proctor, S. P., Constans, J. I., \& Friedman, M. J. (2007). PTSD symptoms, life events, and unit cohesion in US soldiers: baseline findings from the neurocognition deployment health study. DTIC Document. PMid: 17721953. https://doi.org/10.1002/jts.20234

Brewin, C. R., Andrews, B., \& Valentine, J. D. (2000). Meta-analysis of risk factors for posttraumatic stress disorder in trauma-exposed adults. Journal of Consulting and Clinical Psychology, 68(5), 748. PMid:11068961. https://doi.org/10.1037/0022-006X.68.5.748

Cardozo, B. L., Bilukha, O. O., Crawford, C. A. G., Shaikh, I., Wolfe, M. I., Gerber, M. L., \& Anderson, M. (2004). Mental health, social functioning, and disability in postwar Afghanistan. JAMA, 292(5), 575-584. PMid:15292083. https://doi.org/10.1001/jama.292.5.575

Carlson, P. (2016). Trust and health in Eastern Europe: conceptions of a new society. International Journal of Social Welfare, 25(1), 69-77. https://doi.org/10.1111/ijsw.12165

Charmaz, K. (2014). Constructing Grounded Theory. SAGE Publication.

Cohen, S., \& Wills, T. A. (1985). Stress, social support, and the buffering hypothesis. Psychological Bulletin, 98(2), 310. PMid:3901065. https://doi.org/10.1037/0033-2909.98.2.310

Cox, M. (2008). Social capital and peace-building: creating and resolving conflict with trust and social networks. London: Routledge. https://doi.org/10.4324/9780203887837

De Luca, G., \& Verpoorten, M. (2015). Civil war, social capital and resilience in Uganda. Oxford Economic Papers, gpv036. https://doi.org/10.1093/oep/gpv036

Delhey, J., \& Newton, K. (2003). Who trusts?: The origins of social trust in seven societies. European Societies, 5(2), 93-137. https://doi.org/10.1080/1461669032000072256

Deng, L. B. (2010). Social capital and civil war: The Dinka communities in Sudan's civil war. African Affairs, 109(435), 231-250. https://doi.org/10.1093/afraf/adq001

Eriksson, M. (2011). Social capital and health-implications for health promotion. Global Health Action, 4. PMid:21311607; PMCid:PMC3036711. https://doi.org/10.3402/gha.v4i0.5611

Eriksson, M. \& Emmelin, M. (2016). Challenges and opportunities for local development initiatives to influence social capital for health promotion purposes: theoretical and empirical support. In J.P. Larsson \& H. Westlund (Eds.) Handbook of Social Capital and Regional Development (pp. 359-390). Cheltenham, Glos: Edward Elgar Publishing. https://doi.org/10.4337/9781783476831.00020

Ferlander, S. (2007). The importance of different forms of social capital for health. Acta Sociologica, 50(2), 115-128. https://doi.org/10.1177/0001699307077654 
Gatskova, K., \& Gatskov, M. (2016). Third Sector in Ukraine: Civic Engagement Before and After the "Euromaidan". VOLUNTAS: International Journal of Voluntary and Nonprofit Organizations, 27(2), 673-694. https://doi.org/10.1007/s11266-015-9626-7

Giuliano, E. (2015). The social bases of support for self-determination in East Ukraine. Ethnopolitics, 14(5), 513-522. https://doi.org/10.1080/17449057.2015.1051813

Global Peace Index. Retrieved Septemeber 16, 2016 from: www.visionofhumanity.org/\#page/indexes/global-peace-index/2016/UKR/OVER

Heinecken, L. (2015). The military, war and society: the need for critical sociological engagement. Scientia Militaria: South African Journal of Military Studies, 43(1), 1-16. https://doi.org/10.5787/43-1-1107

Heinsch, R. (2015). Conflict Classification in Ukraine: The Return of the "Proxy War"? International Law Studies, 91(1), 9 .

ICT Services and System Development and Division of Epidemiology and Global Health (2013). OpenCode 3.4. Umeå: $\quad$ Umeå University; $2013 . \quad$ Website: http://www.phmed.umu.se/english/units/epidemiology/research/open-code/ [cited 2016 August 28].

Johnson, H., \& Thompson, A. (2008). The development and maintenance of post-traumatic stress disorder (PTSD) in civilian adult survivors of war trauma and torture: A review. Clinical Psychology Review, 28(1), 36-47. PMid:17383783. https://doi.org/10.1016/j.cpr.2007.01.017

Karhina, K., Ng, N., Ghazinour, M., \& Eriksson, M. (2016). Gender differences in the association between cognitive social capital, self-rated health, and depressive symptoms: a comparative analysis of Sweden and Ukraine. International Journal of Mental Health Systems, 10(1), 37. PMid:27148401; PMCid:PMC4855473. https://doi.org/10.1186/s13033-016-0068-4

Kawachi, I., \& Berkman, L. F. (2001). Social ties and mental health. Journal of Urban health, 78(3), $458-467$. PMid:11564849; PMCid:PMC3455910. https://doi.org/10.1093/jurban/78.3.458

Kessler, R. C., Sonnega, A., Bromet, E., Hughes, M., \& Nelson, C. B. (1995). Posttraumatic stress disorder in the National Comorbidity Survey. Archives of General Psychiatry, 52(12), 1048-1060. https://doi.org/10.1001/archpsyc.1995.03950240066012

KHMdepo. Khmelnitsky depo. $\quad$ Retrieved $18 \quad$ September 2016 from http://khm.depo.ua/ukr/khm/hmelnichchina-trimae-liderstvo-u-mobilizatsiyi-06082015110200

Kienzler, H. (2008). Debating war-trauma and post-traumatic stress disorder (PTSD) in an interdisciplinary arena. Social Science \& Medicine, 67(2), 218-227. https://doi.org/10.1016/j.socscimed.2008.03.030

Korac, M. (2008). Gender, conflict, and social capital: Bonding and bridging in war in the former Yugoslavia. In Cox, Michaelene (Ed.) Social Capital and Peace-Building: Creating and Resolving Conflict with Trust and Social Networks. London: Routledge, pp. 107-121.

Mehmet, K. A., \& Mehmet, O. (2004). Family in war and conflict: Using social capital for survival in war torn Cyprus. Journal of Comparative Family Studies, 295-309.

Miller, K. E., Omidian, P., Rasmussen, A., Yaqubi, A., \& Daudzai, H. (2008). Daily stressors, war experiences, and mental health in Afghanistan. Transcultural Psychiatry, 45(4), 611-638. https://doi.org/10.1177/1363461508100785

Murthy, R. S., \& Lakshminarayana, R. (2006). Mental health consequences of war: a brief review of research findings. World Psychiatry, 5(1), 25-30. PMid: 1472271.

Portes, A. (1998). Social capital: Its origins and applications in modern sociology. Annual Review of Sociology, 24(1), 1-24. https://doi.org/10.1146/annurev.soc.24.1.1

Ragin, C. C. (1992). Introduction: Cases of "What is a case?" In C.C. Ragin \& H.S. Becker (Eds.)What is a Case, Exploring the Foundations of Social Inquiry, pp.1-17. New York: Cambridge University Press.

Sas, L. M., \& Yastremska, S. O. (2016). Main Features of Mental Disorders in Individuals Participating in Armed Conflict in the East of Ukraine. Social, Health, and Communication Studies Journal, 2(1), 38-51.

Scholte, W. F., Olff, M., Ventevogel, P., de Vries, G.-J., Jansveld, E., Cardozo, B. L., \& Crawford, C. A. G. (2004). Mental health symptoms following war and repression in eastern Afghanistan. JAMA, 292(5), 585-593. https://doi.org/10.1001/jama.292.5.585 
Stolle, D. (2003). The sources of social capital. In M. Hooghe, D. Stolle (Eds.) Generating social capital. Civil Society and Institutions in Comparative Perspective (pp. 19-42). Palgrave Macmillan US. . https://doi.org/10.1057/9781403979544_2

Summerfield, D. (2000). War and mental health: a brief overview. British Medical Journal, 321(7255), 232. https://doi.org/10.1136/bmj.321.7255.232

Uchino, B. N., Bowen, K., Carlisle, M., \& Birmingham, W. (2012). Psychological pathways linking social support to health outcomes: A visit with the "ghosts" of research past, present, and future. Social Science \& Medicine, 74(7), 949-957. https://doi.org/10.1016/j.socscimed.2011.11.023

UNHCR, 2015. UNHCR Global Appeal 2015 Update. Retrieved from www.unhcr.org/5461e60c47.pdf

Uphoff, N. (2000). Understanding social capital: learning from the analysis and experience of participation. In P. Dasgupta \& I. Serageldin (Eds.) Social capital: A multifaceted perspective, 215-249. Washington DC: The World Bank.

Whiteford, H., Cullen, M., \& Baingana, F. (2005). Social Capital and Mental Health. In: H Herrman, S Saxena \& R Moodie (Eds.) Promoting Mental Health: Concepts, emerging evidence, practice. A WHO Report in collaboration with the Victorian Health Promotion Foundation and the University of Melbourne. Geneva, Switzerland: World Health Organization.

Wieviorka, M. (1992). Case studies: History or sociology. In C.C. Ragin \& H.S. Becker (Eds.) What is a Case, Exploring the Foundations of Social Inquiry, pp. 159-172. New York: Cambridge University Press.

World Health Organization. World Health Report 2001 - Mental health: new understanding, new hope. Geneva: Switzerland, 2001.

\section{Copyrights}

Copyright for this article is retained by the author(s), with first publication rights granted to the journal.

This is an open-access article distributed under the terms and conditions of the Creative Commons Attribution license (http://creativecommons.org/licenses/by/4.0/). 